\title{
Frailty and quality of life: a cross-sectional study of Brazilian patients with pre-dialysis chronic kidney disease
}

Henrique Novais Mansur ${ }^{1,2,3^{*}}$, Fernando AB Colugnati ${ }^{2}$, Fabiane Rossi dos Santos Grincenkov ${ }^{2}$ and Marcus Gomes Bastos ${ }^{2}$

\begin{abstract}
Purpose: Chronic kidney disease (CKD) induces frailty and worsens quality of life (QOL), even in the early stages of the disease and in young patients. However, there is a lack of knowledge about the relationship between frailty and QOL in CKD patients. Thus, we investigated this relationship in a sample of CKD patients.

Methods: A cross-observational study was conducted, in which 61 CKD patients receiving pre-dialysis treatment were assessed. All participants completed the Short Form-36 Health Survey (SF-36). We used valid and reliable methods to classify subjects as frail or non-frail according to Johansen's et al. (2007) criteria. A one-way analysis of variance (ANOVA) and chi-square tests were used to compare the groups. In addition, Spearman's correlation analysis was conducted to measure associations between identified variables and frailty. We also performed simple linear regression using the SF-36 physical and mental composite scores.

Results: Almost half of the sample (42.6\%) exhibited evidence of frailty. The groups differed significantly in terms of age, gender, and all SF-36 domains, excluding Social Functioning and Role Emotional. Frailty was significantly associated with all SF-36 domains, again excluding Social Functioning and Role Emotional. Regression analysis revealed no significant between-group differences in composite physical and mental health scores generated by the SF-36 ( $p>0.05)$.

Conclusion: Frail and non-frail CKD patients differed significantly in seven of the eight SF-36 domains. The frail group displayed diminished physical and mental functioning when their SF-36 scores were divided by their physical and mental composite scores. Frailty was correlated with QOL domains, with the exception of the social domain. There is a need for interventions targeting the characteristics of frailty, to provide better treatment and optimize overall QOL.
\end{abstract}

Keywords: Frailty, Aging, Quality of life, Chronic kidney disease

\footnotetext{
* Correspondence: hnmansur@gmail.com

${ }^{1}$ Federal University of Pernambuco, Academic Centre of Vitória, Alto do

Reservatório Street, no number, Bela Vista, Vitória do Santo Antão,

Pernambuco, Brazil

${ }^{2}$ IMEPEN Foundation, Federal University of Juiz de Fora, José Lourenço

Kelmer Street, 1300, São Pedro, Juiz de Fora, Minas Gerais, Brazil

Full list of author information is available at the end of the article
} 


\begin{abstract}
Introdução: É conhecido que a doença renal crônica implica em pior qualidade de vida e em fragilidade, mesmo em fases iniciais da doença e em sujeitos mais jovens. Existe uma lacuna no conhecimento relacionando fragilidade e qualidade de vida em pacientes com doença renal crônica (DRC), em especial nos pacientes em pré-diálise. Objetivo: Investigar a qualidade de vida, a fragilidade e as possíveis relações entre elas, em uma população com DRC.

Métodos: Estudo observacional e transversal com 61 pacientes com DRC entre os estágios 3 a 5 em fase pré-dialítica. Os participantes responderam à escala do questionário SF-36, que se caracteriza por uma versão reduzida do questionário da Medical Outcomes Study, traduzida e validada para o português. Para avaliação da fragilidade, utilizamos a proposta de Johansen et al. (2007), sendo os sujeitos classificados em frágeis e não frágeis. A comparação entre os grupos foi realizada por ANOVA one-way com análise post hoc de Tukey e pelo teste de qui-quadrado, conforme o tipo de variável analisada. Além disso, foi realizada a correlação de Pearson ou Spearman para medir a associação entre variáveis identificadas e a fragilidade. Realizamos, também, uma regressão linear simples, ajustada para sexo e idade pelos escores físico e mental do SF-36.
\end{abstract}

Resultados: A média de idade foi 60,5 \pm 11,5 anos. Do total de pacientes, 42,6\% apresentavam fragilidade. Os grupos foram diferentes entre si quanto à idade, ao sexo e todos os domínios do SF-36, exceto nos aspectos sociais e nos aspectos emocionais. Quando correlacionamos a fragilidade com as variáveis do estudo, encontramos forte associação com todos os domínios da qualidade de vida, exceto nos aspectos sociais e nos aspectos emocionais. Através da análise de regressão ajustada para idade e sexo, houve diferença entre o grupo frágil no escore físico e no escore mental.

Conclusão: Dos oito domínios do SF-36, sete foram diferentes entre os grupos de fragilidade e, quando separados pelo score físico e mental, o grupo frágil mostrou-se pior. Além disso, também houve correlação entre fragilidade e os domínios de qualidade de vida, com exceção aos aspectos sociais. Intervenções sobre os componentes da fragilidade são necessários para melhor conduzir o tratamento dos pacientes e melhorar sua qualidade de vida.

Palavras-chave: Fragilidade, Idosos, Qualidade de vida, Doença Renal crônica

\section{Introduction}

Frailty is emerging as a common syndrome among older adults. However, for patients with chronic kidney disease (CKD), frailty has also been observed in younger age groups $[1,2]$. This observation reflects a decline in physical functioning and an increase in patient vulnerability [3]. Frailty may even indicate an increased risk of adverse health effects such as morbidity and mortality [4], further reducing patients' quality of life (QOL).

Furthermore, frailty may lead to a worsening of the patient's QOL, possibly due to a reduction in functional capacity, which increases physical fatigue. Both of these issues reduce the patient's mobility, thus lowering social interaction and generating dependency, which can be aggravated in people with clinical complications such as those related to CKD.

Some studies have shown that older adults who do not suffer from CKD but exhibit characteristics of frailty (i. e., exhaustion and reduced strength), show evidence of reduced QOL and increased rates of depression [5-8]. Kanauchi et al. [5] assessed the relationship between frailty, QOL, and wellbeing in older people with cardiometabolic risk factors. Lúpon et al. [6] observed frailty and depressive symptoms in patients with heart failure. Bilotta et al. [9] assessed the relationship between frailty and QOL dimensions in an older Italian population and found reduced QOL in frail participants, as did Lin et al. [10] when studying an older Thai population.

However, to our knowledge, previous studies have not explicitly examined relationships between frailty, QOL, and depression in CKD patients. Because frailty is exacerbated and QOL reduced during the progression of CKD $[3,11,12]$, immediate diagnosis of both is necessary for the implementation of therapeutic interventions designed to minimize further complications.

Thus, the goal of the current study was to evaluate the relationship between frailty and QOL in pre-dialysis CKD patients.

\section{Materials and methods \\ Sample}

The Research Ethics Committee of the Federal University of Juiz de Fora approved the current study. All patients provided written informed consent for participation in this study. The sample comprised male and female adults $(N=$ 61) receiving pre-dialysis treatment for Stages 3-5 CKD. Patients were excluded if they presented with clinical conditions diagnosed by a physician that would impede physical assessment (e.g., severe neurological pathologies, gout, amputations, Parkinson's disease, chronic obstructive pulmonary disease, neoplasms, human immunodeficiency virus, and severe physical sequelae caused by stroke or deep 
vein thrombosis). Patients were also deemed ineligible if they exhibited significant cognitive decline, measured using a translated and adapted version [13] of the Mini-Mental State Examination [14].

\section{Evaluation of kidney function and comorbidities}

The diagnosis of CKD and disease stage was established by estimating patients' glomerular filtration rate (GFR), based on serum creatinine $(\mathrm{Cr})$ dosage, using a formula developed for the MDRD study proposed by the National Kidney Foundation [15]. Diagnosis was also confirmed through documentation of renal parenchymal injury (i.e., proteinuria and/or abnormal glomerular hematuria) existing for a period exceeding three months.

\section{Frailty}

Frailty was evaluated via indicators of muscle weakness (a Short Form-36 Health Survey (SF-36) physical function score $\geq 75$ points), exhaustion (an SF-36 vitality score $\geq 55$ points), physical inactivity (whether a patient responded "never" or "almost never" to a question about the frequency of physical activity), and/or unintentional weight loss of over $5 \mathrm{~kg}$ in the preceding year [1].

The muscle weakness criterion was worth 2 points, while the others were worth 1 point. A patient with a summed score between 0 and 2 points was categorized as non-frail (NF) while a patient with a score of $\geq 3$ points was categorized as frail (F).

\section{Quality of life}

The SF-36 is a shortened version of a questionnaire used in the Medical Outcomes Study. It has been translated and validated for Portuguese respondents in order to assess QOL in this population [16]. The following QOL domains were evaluated: Physical Functioning, Role Physical, Bodily Pain, General Health, Vitality, Social Functioning, Role Emotional, and Mental Health. While the SF-36 has no cut-off point, scores that vary from 0 to 100 are assigned to each domain. Lower scores indicate poorer QOL [17].

Using the Ware Algorithm [18], we transformed the eight domains into two composite domains: a physical component domain (comprising functional capacity, indices of physical functioning, pain, general health, and vitality) and a mental component domain (comprising indices of social functioning, emotional functioning, mental health, general health, and vitality).

\section{Statistical analyses}

We used SPSS version 17.0 (SPSS Inc., Chicago, Illinois) or STATA version 11.0 (StataCorp LP, College Station, Texas) for all analyses.

Patient characteristics, including demographic, clinical, and laboratory characteristics, were presented as means \pm $\mathrm{SD}$ or frequencies (i.e., percentage of the total). All variables met the assumptions of normality as indicated by the Kolmogorov-Smirnov test. Comparisons between the two groups were performed using independent-sample $t$-tests.

Chi-square tests were performed in order to identify categorical variables associated with frailty, and Spearman's correlation analysis was used to measure associations between identified variables and frailty.

To evaluate differences in standardized SF-36 scores between frailty groups, we used a multiple regression model with frailty variables. The NF condition was used as a reference. The model controlled for gender and age. Results were expressed as adjusted means, and differences were assessed between these for patients categorized as NF. The significance threshold was 0.05 .

\section{Results}

The mean age of the sample was $60.5 \pm 11.5$ years, and $42.6 \%$ of the participants were diagnosed as frail. Table 1 shows the demographic, clinical, and laboratory data for patients, divided into F and NF groups. The groups differed significantly in terms of age $(p=0.009)$, gender $(p=0.02)$, and all QOL domains (Physical Functioning: $\mathrm{p}=0.0001$; Role Physical: $\mathrm{p}=0.03$; Bodily Pain: $\mathrm{p}=0.03$; General Health: $\mathrm{p}=0.04$; Vitality: $\mathrm{p}=0.002$; Mental Health: $\mathrm{p}=0.05$ ) except Social Functioning and Role Emotional. However, they did not differ in race, body mass index (BMI), smoking status, CKD stage, CKD etiology, comorbidities, $\mathrm{Cr}$ level, or GFR.

Table 2 shows the association between frailty and demographic, laboratory, and QOL variables. Frailty did not correlate with $\mathrm{Cr}$ or GFR but correlated significantly with all QOL domains (Physical Functioning: $r=-0.82, p=0.0001$; Role Physical: $\mathrm{r}=-0.41, \mathrm{p}=0.001$; Bodily Pain: $\mathrm{r}=-0.28, \mathrm{p}=$ 0.03; General Health: $\mathrm{r}=-0.31, \mathrm{p}=0.001$; Vitality: $\mathrm{r}=-0.57$, $\mathrm{p}=0.0001$; Mental Health: $\mathrm{r}=-0.36, \mathrm{p}=0.05$ ) except Social Functioning and Role Emotional.

QOL represents multiple factors related to patients' perception of their own lives. In an effort to understand which domains were most strongly associated to frailty, we assessed differences between the F and NF groups based on the composite physical and mental SF-36 domains.

As indicated in Table 3 and Figure 1, simple linear regression adjusted for age and gender revealed a significant difference between groups for the physical (cof $=-1.12[-1.47$ to -0.76$], \mathrm{p}=0.001)$ and mental ( $\mathrm{cof}=-0.75[-1.4$ to -0.16$]$, $\mathrm{p}=0.02)$ SF-36 components.

\section{Discussion}

The purpose of the current study was to verify the relationship between QOL and frailty in pre-dialysis CKD patients. The prevalence of frailty in the current sample (42.6\%) fell between that documented in other samples $(67.7 \%$ and $20.9 \%,[1,3])$. It should be noted, however, 
Table 1 Details of demographic and clinical data, as well as biochemical parameters, of the total sample $(n=61)$ and separated by frailty classification in a group of Brazilian patients with pre-dialysis chronic kidney disease

\begin{tabular}{|c|c|c|c|c|}
\hline & Total $(n=61)$ & Non-frail $(n=35)$ & Frail $(n=26)$ & $p$ \\
\hline & \multicolumn{4}{|c|}{ Mean \pm SD or $n(\%)$} \\
\hline Age (years) & $60.5 \pm 11.5$ & $57.3 \pm 11.4$ & $64.9 \pm 10.3$ & $0.009^{*}$ \\
\hline Female & $25(41.0 \%)$ & $10(28.6 \%)$ & $15(57.7 \%)$ & $0.02^{*}$ \\
\hline Black phenotype & $28(45.9 \%)$ & $13(37.1 \%)$ & $11(42.3 \%)$ & 0.11 \\
\hline Body mass index $\left(\mathrm{kg} / \mathrm{m}^{2}\right)$ & $25.9 \pm 5.0$ & $26.2 \pm 4.0$ & $28.0 \pm 5.5$ & 0.16 \\
\hline Smoking status & $9(14.8 \%)$ & $5(14.3 \%)$ & $4(15.4 \%)$ & 0.90 \\
\hline Chronic kidney disease stages & & & & 0.15 \\
\hline 3 & $24(39.3 \%)$ & $17(48.6 \%)$ & $7(26.9 \%)$ & \\
\hline 4 & $25(42.6 \%)$ & $12(34.3 \%)$ & $13(50.0 \%)$ & \\
\hline 5 & $12(19.7 \%)$ & $6(17.1 \%)$ & $6(23.1 \%)$ & \\
\hline Etiology of chronic kidney disease & & & & 0.56 \\
\hline Arterial hypertension & $18(29.5 \%)$ & $11(31.4 \%)$ & $7(26.9 \%)$ & \\
\hline Diabetes mellitus & $11(18.0 \%)$ & $4(11.4 \%)$ & $7(26.9 \%)$ & \\
\hline Glomerulonephritis & $9(14.8 \%)$ & $7(20.0 \%)$ & $2(7.7 \%)$ & \\
\hline Unknown & $8(13.1 \%)$ & $4(11.4 \%)$ & $4(15.4 \%)$ & \\
\hline Undetermined or other & $15(24.6 \%)$ & $9(25.7 \%)$ & $6(23.1 \%)$ & \\
\hline Comorbidities & & & & 0.10 \\
\hline Arterial hypertension & $23(56.1 \%)$ & $14(40.0 \%)$ & $9(34.6 \%)$ & \\
\hline Diabetes mellitus & $4(9.8 \%)$ & $3(8.6 \%)$ & $1(2.6 \%)$ & \\
\hline Other & $25(41.0 \%)$ & $11(31.5 \%)$ & $14(53.9 \%)$ & \\
\hline None & $9(22.0 \%)$ & $7(20.0 \%)$ & $2(7.7 \%)$ & \\
\hline Creatinine $(\mathrm{mg} / \mathrm{dL})$ & $2.7 \pm 1.3$ & $2.7 \pm 1.5$ & $2.7 \pm 1.0$ & 0.89 \\
\hline Glomerular filtration rate $\left(\mathrm{mL} / \mathrm{min} / 1.73 \mathrm{~m}^{2}\right)$ & $26.8 \pm 12.9$ & $28.6 \pm 13.1$ & $24.3 \pm 12.5$ & 0.19 \\
\hline \multicolumn{5}{|l|}{ SF-36 domains } \\
\hline Physical functioning & $67.2 \pm 25.3$ & $84 \pm 15.3$ & $46 \pm 19$ & $0.0001^{*}$ \\
\hline Role physical & $65.9 \pm 38.7$ & $75 \pm 35.3$ & $53.8 \pm 40.4$ & $0.03^{*}$ \\
\hline Bodily pain & $68.8 \pm 31.7$ & $76.5 \pm 26.7$ & $58.4 \pm 35.3$ & $0.03^{*}$ \\
\hline General health & $56.4 \pm 25.2$ & $62 \pm 23.8$ & $48.9 \pm 25.6$ & $0.04^{*}$ \\
\hline Vitality & $69.5 \pm 23.3$ & $77.4 \pm 21.6$ & $58.8 \pm 21.5$ & $0.002^{*}$ \\
\hline Social functioning & $85.4 \pm 25.7$ & $84.9 \pm 28.4$ & $86 \pm 22.1$ & 0.87 \\
\hline Role emotional & $74.5 \pm 37.2$ & $76.1 \pm 36.7$ & $72.3 \pm 38.5$ & 0.69 \\
\hline Mental health & $76.0 \pm 22.3$ & $80.8 \pm 21.3$ & $69.5 \pm 22.5$ & $0.05^{*}$ \\
\hline
\end{tabular}

that the instruments used to assess frailty in previous studies differed from those used in the current study.

As in this study, others have associated frailty with diminished QOL in older adults with various pathologies. These results are similar despite differences in the instruments used to evaluate QOL and frailty.

Kanauchi et al. [5] evaluated 101 older patients with cardiometabolic risk factors and concluded that frail patients had decreased QOL as assessed by the Vulnerability Elderly Survey Index (VESI) and all domains of the World Health Organization QOL (WHOQOL) assessment.
In a cross-sectional study, Bilotta et al. [9] examined older Italian participants from the Study of Osteoporotic Fractures (SOF), which correlated frailty with QOL life domains from the Older People Quality of Life (OPQOL) instrument. Similar to the results in our study, there was no relationship between frailty and QOL domains except social relationships and financial circumstances.

Using the SF-36, Lin et al. [10] analyzed the relationship between frailty through a phenotype proposed by Fried et al. [7] and QOL domains in 933 older participants in Taiwan. The results demonstrated that frailty was associated with all domains except for the physical, emotional, 
Table 2 Correlation between frailty criteria and age, creatinine, glomerular filtration rate, and quality of life domains in a group of Brazilian patients with pre-dialysis chronic kidney disease

\begin{tabular}{lcc}
\hline & $\mathbf{R}$ & $\mathbf{p}$ \\
\hline Age & 0.25 & 0.05 \\
Creatinine & 0.08 & 0.55 \\
Glomerular filtration rate & -0.15 & 0.24 \\
Functional capacity & -0.82 & $0.0001^{*}$ \\
Physical aspects & -0.41 & $0.001^{*}$ \\
Pain & -0.28 & $0.03^{*}$ \\
General state of health & -0.31 & $0.001^{*}$ \\
Vitality & -0.57 & $0.0001^{*}$ \\
Social aspects & -0.12 & 0.36 \\
Emotional aspects & -0.19 & 0.14 \\
Mental health & -0.36 & $0.005^{*}$ \\
\hline * $<$ 0.05. & &
\end{tabular}

and mental domains. In our study, the only QOL domains that were not significantly associated with frailty were the emotional and social domains; however, there was a relationship between frailty and the physical and mental composite domains.

The relationship between frailty and depression is also relevant. This relationship will be clarified in prospective studies that plan to verify the associations between QOL, depression, frailty, and negative outcomes (e.g., hospitalization and mortality).

Lúpon et al. [6] evaluated the relationship between frailty and depression in 622 hospitalized patients with heart failure who died one year post-assessment. Frailty and depression were associated with worse outcomes. However, only frailty held prognostic value for mortality, even after adjusting for confounds in the multivariate analyses. In their study, the QOL measure-the Minnesota Living with Heart Failure Questionnaire-was not associated with either frailty or depression.

In another analysis, Masel et al. [8] evaluated the relationship between frailty, QOL, and mortality in 1,008 older Mexicans over periods of two and three years. QOL was assessed using the SF-36. Frailty was associated with mortality during the study period; however, this association was attenuated following adjustment of the SF-36 physical domain.

A relationship between QOL and depression in CKD patients has been observed [19-23]. However, previous studies have not assessed the association between frailty and QOL in this patient population.

Regarding the relationship between frailty and QOL, we argue that frailty directly influences QOL by reducing patients' physical and functional capacity. This, in turn, exacerbates symptoms related to the mental domain.

In CKD, the relationship between frailty and QOL is due to specific factors, including weakness, fatigue, weight loss, low levels of physical activity, social exclusion, mild cognitive changes, and increased vulnerability to stressors [7].

We evaluated depression within a sub-sample of patients in our study $(n=37)$ using the Beck Depression Inventory (BDI). We did not find a relationship between frailty and depression (data not shown).

However, some studies, such as the Netherlands Cooperative Study on the Adequacy of Dialysis (NECOSAD) project conducted by Van Den Beukel et al. [24], have assessed depression by using the mental health and emotional domains or the mental composite score. When the mental health domain was used as an indicator of negative mood, our data confirmed an association between frailty and depression. Chang et al. [25], when evaluating 1,240 patients from the Women's Health and Aging Studies (WHAS) I and II, recently revealed a similar result.

We also found a difference between frailty groups with respect to age and gender, with the frail group comprising patients who were older and predominantly female. This is similar to the majority of studies that have assessed frailty.

Fried et al. [7] found that age was a contributing factor to the frailty of 5,317 older patients without CKD from the Cardiovascular Health Study (CHS). Women, regardless of age, were more frail then men. Shilipak et al. [26] compared 5,808 older patients with and without CKD and found a higher prevalence of frailty among black women, regardless of CKD status.

In another large study assessing frailty in CKD patients, Johansen et al. [1] observed that frailty was more

Table 3 Differences between frailty groups on composite SF-36 physical and mental scores in a group of Brazilian patients with pre-dialysis chronic kidney disease

\begin{tabular}{|c|c|c|c|c|c|c|}
\hline & \multicolumn{3}{|c|}{ Mental component } & \multicolumn{3}{|c|}{ Physical component } \\
\hline & Mean* & Coeficient & $p$ & Mean* & Coeficient & $p$ \\
\hline Non-frail & -1.1 & - & & -1.12 & - & \\
\hline Frail & -1.81 & $-0.75(-1.4 ;-0.16)$ & 0.02 & 0.6 & $-1.12(-1.47 ;-0.76)$ & $<0.001$ \\
\hline
\end{tabular}

*Averages adjusted for gender and age in years. 


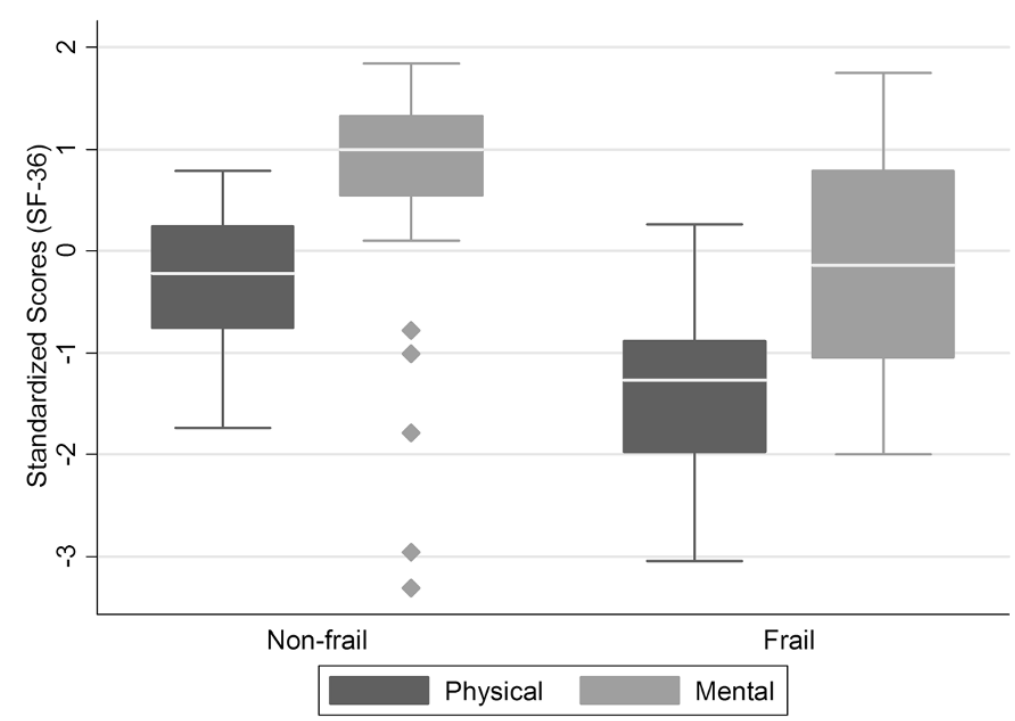

Figure 1 Box plot showing the difference between the non frailty and frailty groups on physical and mental component scores.

prevalent in patients on hemodialysis and peritoneal dialysis and was associated with gender (i.e., women were $55 \%$ more likely than men to be frail). In addition, this study demonstrated that age was not a reliable predictor of frailty since it was also observed in a significant portion of younger adults.

The current study has some notable limitations. First, we utilized a cross-sectional design, which was restricted to assessing whether there were associations between frailty, QOL, and depression (i.e., no causal inferences can be made). Second, our study employed a small sample recruited from a single treatment center.

We can better manage patient health by exploring the QOL domains that are affected by frailty. Thus, several strategies should be implemented to improve QOL, including physical exercise, treatment of anemia, maintaining hormonal balance, stress management, reduction of inflammation, and treatment for depression.

Additional longitudinal studies evaluating frailty, depression, and QOL among patients with CKD, particularly those undergoing pre-dialysis treatment, are required to clarify these relationships further.

\section{Conclusion}

The data presented in the current study allowed us to conclude that of the eight SF-36 domains, seven were significantly different between frail and non-frail CKD patients. When separated according to physical and mental scores, frail patients performed more poorly. In addition, there were correlations between frailty and QOL domains, excluding indices of social functioning. Therapeutic interventions applied to the components of frailty are needed in order to implement better patient care and improve QOL.
Competing interests

The authors declare that they have no competing interests.

\section{Author's contributions}

HNM and FRSG were responsible for the execution of the study and writing the manuscript. FABC and MGB were responsible for statistical analysis and critical review of the study. All authors read and approved the final manuscript.

\section{Author details}

${ }^{1}$ Federal University of Pernambuco, Academic Centre of Vitória, Alto do Reservatório Street, no number, Bela Vista, Vitória do Santo Antão, Pernambuco, Brazil. ${ }^{2}$ IMEPEN Foundation, Federal University of Juiz de Fora, José Lourenço Kelmer Street, 1300, São Pedro, Juiz de Fora, Minas Gerais, Brazil. ${ }^{3}$ Wolfgang Amadeus Mozart Street, 131, São Pedro, Juiz de Fora, Minas Gerais, Brazil.

Received: 15 November 2013 Accepted: 21 February 2014 Published: 28 February 2014

\section{References}

1. Johansen LK, Chertow GM, Jin C, Kutner NG: Significance of frailty among dialysis patients. J Am Soc Nephrol 2007, 18:2960-2967.

2. Mansur HN, Damasceno VO, Bastos MG: Prevalence of frailty in patients with chronic kidney disease not yet and on dialysis. Brazil J Nephrol 2012, 34:153-160.

3. Wilhelm-Leen ER, Hall YN, Tamura MK, Chertow GM: Frailty and chronic kidney disease: the third national health and nutrition evaluation survey. Am J Med 2009, 7:664-671.

4. Karnik K, Mazzatti DJ: Review of tools and technologies to assess multisystem functional impairment and frailty. Clin Med Geriatr 2009, 3:1-8.

5. Kanauchi M, Kubo A, Kanauchi K, Saito Y: Frailty, health-related quality of life and mental wellbeing in older adults with cardiometabolic risk factors. Int J Clin Pract 2008, 62:1447-1451.

6. Lúpon J, González B, Santaeugenia S, Altimir S, Urrutia A, Más D, Dias C, Pascual T, Cano L, Valle V: Prognostic implication of frailty and depressive symptoms in an outpatient population with heart failure. Spanish $J$ Cardiol 2008, 61:835-842.

7. Fried LP, Tangen CM, Walston J, Newman AB, Hirsch C, Gottdiener J, Seeman T, Tracy R, Kop WJ, Burke G, McBurnie MA, Cardiovascular Health Study Collaborative Research Group: Collaborative research group for the cardiovascular health study: frailty in older adults: evidence for a phenotype. J Gerontol A Biol Med Sci 2001, 56A:M146-M156.

8. Masel MC, Ostir GV, Ottenbache KJ: Frailty, mortality, and health related quality of life in older Mexican Americans. J Am Geriatr Soc 2010, 58:2149-2153. 
9. Bilotta C, Bowling A, Case A, Nicolini P, Mauri S, Castelli M, Vergani C: Dimensions and correlates of quality of life according to frailty status: a cross-sectional study on community-dwelling older adults referred to an outpatient geriatric service in Italy. Health Qual Life Outcome 2010, 8:56.

10. Lin CC, Li Cl, Chang CK, Liu CS, Lin CH, Meng NH, Lee YD, Cheen FN, Li TC: Reduced health-related quality of life in elders with frailty: a cross-sectional study of community-dwelling elders in Taiwan. PLoS One 2011, 6:1-7.

11. Chan R, Brooks R, Erlich J, Chow J, Suryani M: The effects of kidney-diseaserelated loss on long-term dialysis patients' depression and quality of life: positive affect as a mediator. Clin J Am Soc Nephrol 2009, 4:160-167.

12. Bakewell $A B$, Higgins RM, Edmunds MA: Quality of life in peritoneal dialysis patients: decline over time and association with clinical outcomes. Kidney Int 2002, 61:239-248.

13. Brucki SM, Nitrini R, Caramelli P, Bertolucci PH, Okamoto IH: Suggestions for utilization of the mini-mental state examination in Brazil. Neuro-Psychiatry Arch 2003, 61:777-781.

14. Folstein MF, Folstein SE, McHugh PR: "Mini-mental state": a practical method for grading the cognitive state of patients for the clinician. J Psychiatry Res 1975, 12:189-198.

15. National Kidney Foundation: K/DOQI clinical practice guidelines for chronic kidney disease: evaluation, classification and stratification. Am J Kidney Dis 2002, 39(Suppl 2):S1-S246.

16. Cicconelli RM, Ferraz MB, Santos W, Meinão I, Quaresma MR: Tradução para o português e validação do questionário genérico de avaliação de qualidade de vida "medical outcomes study 36-item-short-form health survey (SF-36). Brazil J Rheumatol 1999, 39:143-150.

17. Cicconelli RM: Tradução para o português e validação do questionário genérico de avaliação de qualidade de vida "Medical Outcomes Study 36-itemShort-Form Health Survey (SF-36).", PhD Thesis. São Paulo: Federal University of São Paulo, Medicine School; 1997.

18. Ware JE, Kosinski M, Keller SD: SF-36 physical and mental health summary scales: A user's manual. Boston: New England Medical Center - The Health Institute; 1994

19. Almeida A, Meleiro A: Depressão e insuficiência renal crônica: uma revisão. Brazil J Nephrol 2000, 22:192-200.

20. Almeida AM: Revisão: a importância da saúde mental na qualidade de vida e sobrevida do portador de insuficiência renal crônica. Brazil J Nephrol 2003, 25:209-214.

21. Chow F, Briganti EM, McLinepin KPG, Chadban SJ, Zimmet PZ, Atkins RC: Healthrelated quality of life in Australian adults with renal insufficiency: a population-based study. Am J Kidney Dis 2003, 41:596-604.

22. Revuelta KL, Lopez FJG, Moreno AF, Alonso J: Perceived mental health at the start of dialysis as a predictor of morbidity and mortality in patients with end-stage renal disease. Nephrol Dial Transplant 2004, 19:2347-2353.

23. Cukor D, Coplan J, Brown C, Friedman S, Cromwell-Smith A, Peterson RA, Kimmel PL: Depression and anxiety in urban hemodialysis patients. Clin J Am Soc Nephrol 2007, 2:484-490.

24. Van den Beukel TO, Verduijn M, Le Cessie S, Jager K, Boeschoten EW, Krediet RT, Siegert CE, Honig A, Dekker FW: The role of psychosocial factors in ethnic differences in survival on dialysis in the Netherlands. Nephrol Dial Transplant 2012, 27:2472-2479.

25. Chang SS, Weiss CO, Xue QI, Fried LP: Association between inflammatoryrelated disease burden and frailty: results from the Women's Health and Aging Studies (WHAS) I and II. Arch Gerontol Geriatr 2012, 54:9-15.

26. Shilipak MG, Stehman-Breen C, Fried LF, Song X, Siscovick D, Fried LP, Psaty BM, Newman AB: The presence of frailty in elderly persons with chronic renal insufficiency. Am J Kidney Dis 2004, 43:861-867.

doi:10.1186/1477-7525-12-27

Cite this article as: Mansur et al:: Frailty and quality of life: a cross-sectional study of Brazilian patients with pre-dialysis chronic kidney disease. Health and Quality of Life Outcomes 2014 12:27.

\section{Submit your next manuscript to BioMed Central and take full advantage of:}

- Convenient online submission

- Thorough peer review

- No space constraints or color figure charges

- Immediate publication on acceptance

- Inclusion in PubMed, CAS, Scopus and Google Scholar

- Research which is freely available for redistribution
C Biomed Central 